Original paper

\title{
Platinum-group elements (PGE) and their principal carriers in metal-rich black shales: an overview with a new data from Mo-Ni-PGE black shales (Zunyi region, Guizhou Province, south China)
}

\author{
Jan PAŠAVA ${ }^{1 *}$, Federica ZACCARINI ${ }^{2}$, Thomas AIGLSPERGER ${ }^{3}$, Anna VYMAZALOVÁ ${ }^{1}$ \\ ${ }^{1}$ Czech Geological Survey, Geologická 6, 15200 Prague 5, Czech Republic; jan.pasava@geology.cz \\ ${ }^{2}$ Montanuniversität Leoben, Peter Tunner Str. 5, A-8700 Leoben, Austria \\ ${ }^{3}$ University of Barcelona, C/Marti i Franques s/n, E-08028 Barcelona, Spain \\ * Corresponding author
}

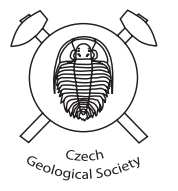

\begin{abstract}
Lower Cambrian Mo-Ni sulfidic black shales from the Huangiiawan mine (Guizhou Province, south China) have anomalous platinum-group elements (PGE) concentrations (up to $\sim 1 \mathrm{ppm}$ in total). In order to identify principal PGE carriers, we used heavy mineral separates which were produced by innovative hydroseparation techniques. Subsequent detailed mineralogical study using electron microprobe did not result in the identification of discrete platinum-group minerals. Pyrite (grainy, not framboidal), millerite and gersdorffite that were found in our heavy concentrate were analyzed for PGE and Re. We found that they contain the following concentrations of PGE and Re: pyrite (up to $490 \mathrm{ppm}$ Pt, 390 ppm Pd and $220 \mathrm{ppm} \mathrm{Rh}$ ), millerite (up to $530 \mathrm{ppm} \mathrm{Pt,} 430 \mathrm{ppm} \mathrm{Pd}$ and $190 \mathrm{ppm} \mathrm{Rh}$ ) and gersdorffite (up to $410 \mathrm{ppm}$ $\mathrm{Pt}$ and $320 \mathrm{ppm} \mathrm{Pd}$; no Rh detected). Rhenium was detected only in grainy pyrite (up to $1060 \mathrm{ppm}$ ). It was found that despite anomalous PGE concentrations, the Mo-Ni black shales do not contain any platinum-group minerals and that the PGE are bound to pyrite and Ni-sulfides (millerite and gersdorffite).
\end{abstract}

Keywords: Mo-Ni-PGE black shale, PGE concentrations in pyrite and Ni-sulfides, Re concentration in pyrite, hydroseparation, electron microprobe study, south China

Received: 18 December 2012; accepted: 19 September 2013; handling editor: D. Dolejš

\section{Introduction}

Anoxic sediments and metasediments have been recently recognized as important host environments for the platinum group elements (PGE) (e.g., Pašava 1993; Sawlowicz 1993). Economically significant PGE concentrations have been reported from marine, metal-rich black shales in China, Yukon (Canada) and Poland (Kucha 1975; Chen et al. 1982; Hulber et al 1992 and others). These ore-bearing horizons are characterized by extremely restricted vertical, and sometimes larger horizontal extents. They are associated with the evolution of intracontinental rifting structures without any magmatic activity, suggesting a possible driving mechanism for mineralization processes (Pašava 1993).

In metal-rich black shales with anomalous PGE concentrations, platinum-group minerals (PGM) have been identified from the so-called noble metal rich black shales within the $\mathrm{Cu}-\mathrm{Ag}$ shales of the Kupferschiefer type (Kucha 1975, 1981, 1982; Piestrzynski et al. 1996; Pieczonka and Piestrzynski 1997 and others), in gold ores hosted by black shales at the Sukhoy Log deposit, Russia (Distler et al. 1998), metalliferous black shales of the Kursk magnetic anomaly (Rudashevsky et al. 1995), Neoproterozoic
U-V-rich black shales of the Onega trough, South Karelia, Russia (Polekhovsky et al. 1991), Palaeoproterozoic U-Au-Pt-Pd black shale hosted Coronation Hill deposit, Australia (Carville at al. 1990) and sulfidic black shales in SW Catalonia (Canet et al. 2003).

The Early Cambrian marine black shales of south and southwest China host Mo-Ni-PGE-Au deposits that outcrop discontinuously throughout six provinces in a belt approximately $1600 \mathrm{~km}$ long (Chen et al. 1982; Fan 1983). The Mo-Ni ore contains more than 4 wt. \% Mo, at least 2 wt. $\% \mathrm{Ni}$, up to 2 wt. $\% \mathrm{Zn}, 2.5$ wt. \% As and 1-2 g/t of precious metals, primarily $\mathrm{Au}, \mathrm{Pt}, \mathrm{Pd}$, and Os (Fan 1983). The deposits are important, particularly because they constitute a largely untested alternative to conventional sources of precious metals, especially PGE (Coveney and Chen 1991; Coveney et al. 1991 and others). Macroscopically, only pyrite can be recognized in ore samples. However, major ore minerals are vaesite, bravoite, jordisite and MoSC phase (Fan 1983; Kao et al. 2001; Orberger et al. 2007). Minor ore minerals include arsenopyrite, chalcopyrite, covellite, sphalerite, millerite, polydymite, gersdorffite, sulvanite, pentlandite, tennantite, tiemannite, violarite, and native gold (Fan 1983; Grauch et al. 1991). A highly porous matrix of the ore 
bed is composed of organic matter or alumosilicate-rich laminae or lenticular bodies that are intercalated with phosphate- or sulfide-rich lenses (Pašava et al. 2008). Various genetic models for the origin of these metal-rich facies were discussed by Coveney and Pašava (2005), including seawater origin of metals (e.g., Mao et al. 2002;
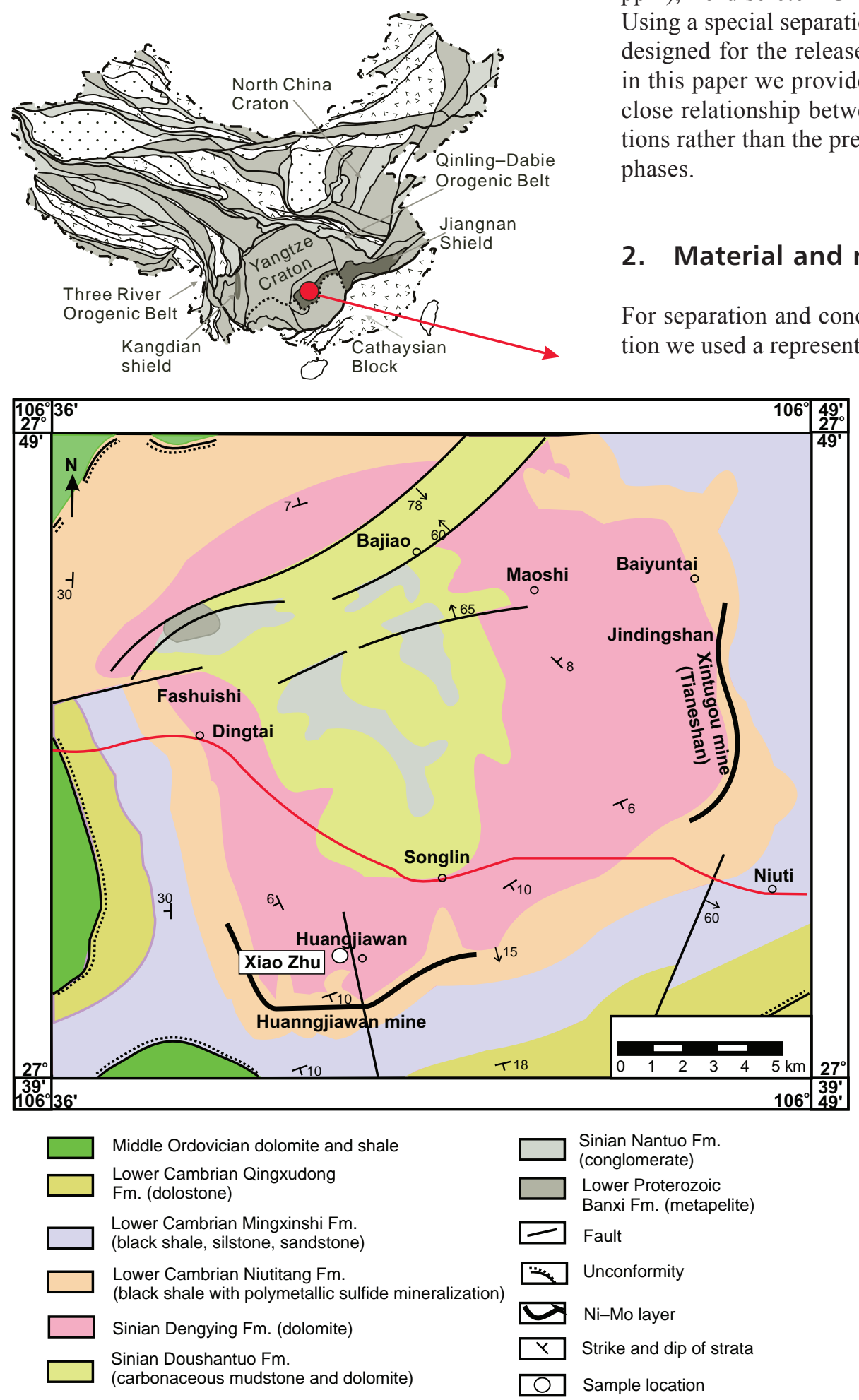

Lehmann et al. 2007; Xu et al. 2011), hydrothermal and/ or multiple metal sources (Lott et al. 1999; Steiner et al. 2001; Orberger et al. 2003; Pašava et al. 2004; Emsbo et al. 2005; Jiang et al. 2006, 2007, 2009; Kř́bek et al. 2007; Pi et al. 2013 and others).

Despite anomalous PGE concentrations ( $\Sigma$ PGE $\sim 1$ ppm), no discrete PGE phases were identified to date. Using a special separation technique which was uniquely designed for the release and concentration of the PGM, in this paper we provide a new evidence that points to a close relationship between sulfides and PGE concentrations rather than the presence of individual discrete PGE phases.

\section{Material and methods}

For separation and concentration of heavy mineral fraction we used a representative sample which was collected from fresh Mo-Ni-PGE orebody at the Huangjiawan mine area, Zunyi region, northern part of the Guizhou Province $\left(27^{\circ} 41^{\prime} 305^{\prime \prime} \mathrm{N} ; 106^{\circ} 40^{\prime} 069^{\prime \prime} \mathrm{E}\right)$. The location and general geology of the sampling area is shown in Fig. 1.

The ore sample contains 7 wt. $\% \mathrm{Mo}, 2 \% \mathrm{Ni}, 19 \% \mathrm{~S}$ and $13 \% \mathrm{C}_{\text {org }}, 10 \% \mathrm{CO}_{2}, 14 \%$ $\mathrm{CaO}, 1.2 \% \mathrm{As}, 2000 \mathrm{ppm} \mathrm{Se}$, $5400 \mathrm{ppm} \mathrm{Zn,} 450 \mathrm{ppm} \mathrm{U}$ and $\mathrm{V}$, and up to $1 \mathrm{ppm}$ PGE (Orberger et al. 2007).

One representative sample (641 g) of Mo-Ni-PGE ore (Figs 2 and 3) was crushed down to a grain size $<125 \mu \mathrm{m}$ by a RETSCH vibratory disc mill (RS 100), using an agate grinding set. The resulting fine fraction was carefully wet sieved by hand through a standard screen series following the methodology given by Aiglsperger et al. (2011). The finest size fraction $(<53 \mu \mathrm{m})$ was processed by hydroseparation (HS-11) techniques (Ru-

Fig. 1 Geological sketch map of the Zunyi region with black shale sampling location, the northern part of the Guizhou Province, southwest China (adapted from Mao et al. 2002, 2013). 


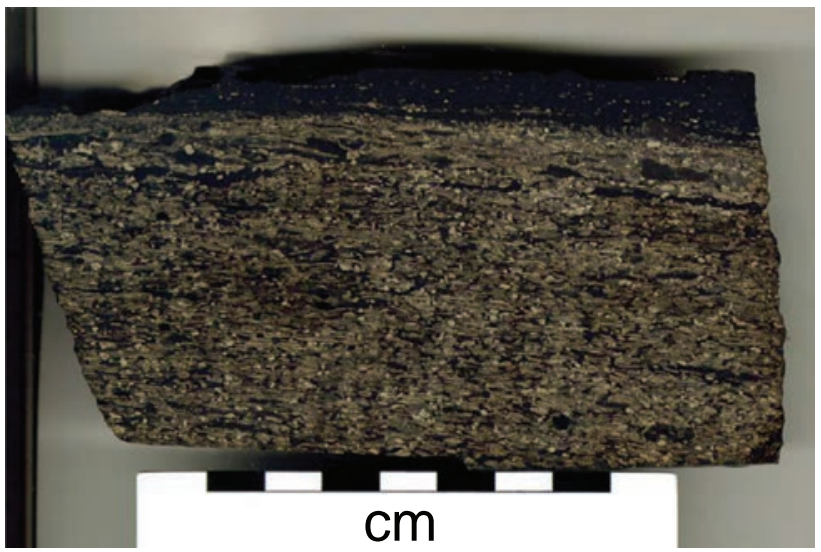

Fig. 2 Typical sample of Ni-Mo black shale showing the texture (photo by J. Pašava).

dashevsky et al. 2001a,b; Cabri et al. 2005; Rudashevsky and Rudashevsky 2006, 2007) at the hydroseparation (HS) laboratory in Barcelona. Monolayer polished sections were produced from $0.25 \mathrm{~g}$ final concentrate and subsequently studied using an electron microprobe (EMP) at the Eugen F. Stumpfl laboratory (University of Leoben, Austria).

Pyrite (493 analyses), millerite (248 analyses) and gersdorffite (66 analyses), (Figs 4 and 5) have been determined by a Jeol Superprobe JXA- 8200 by wavelength dispersive systems (WDS) using $25 \mathrm{kV}$ of accelerating voltage and $30 \mathrm{nA}$ of beam current. The counting times were 120 and $60 \mathrm{~s}$ for the peak and backgrounds, respectively. The beam diameter was $c .1 \mu \mathrm{m}$. The ore minerals were analyzed using pure metals as the reference material for PGE and Re, synthetic NiS, natural pyrite, chalcopyrite, skutterudite and nickeline for $\mathrm{Fe}, \mathrm{Ni}, \mathrm{Cu}, \mathrm{Co}, \mathrm{As}$ and $\mathrm{S}$. The $\mathrm{X}$-ray lines used were: $\mathrm{K}_{\alpha}$ for $\mathrm{S}$, $\mathrm{Fe}, \mathrm{Cu}, \mathrm{Ni}$ and $\mathrm{Co} ; \mathrm{L}_{\alpha}$ for $\mathrm{As}$, $\mathrm{Ru}, \mathrm{Rh}, \mathrm{Pt}$ and Pd; $\mathrm{M}$ for Re. The following diffracting crystals were selected: PETJ for $\mathrm{S}$, PETH for Ru, Rh and Re, LIF for $\mathrm{Cu}, \mathrm{LIFH}$ for $\mathrm{Ni}, \mathrm{Fe}, \mathrm{Co}$ and Pt and TAP for As. The detection limits of the trace elements are (in ppm) As $=70, \mathrm{~S}=80$, $\mathrm{Fe}=70, \mathrm{Ni}=80, \mathrm{Co}=50, \mathrm{Cu}=$ $90, \mathrm{Ru}=60, \mathrm{Rh}=50, \mathrm{Pd}=60$, $\mathrm{Pt}=80, \mathrm{Re}=110$. Automatic

Fig. 4 Backscattered electron image of studied ore minerals (millerite, gersdorffite and pyrite), photo by F. Zaccarini.

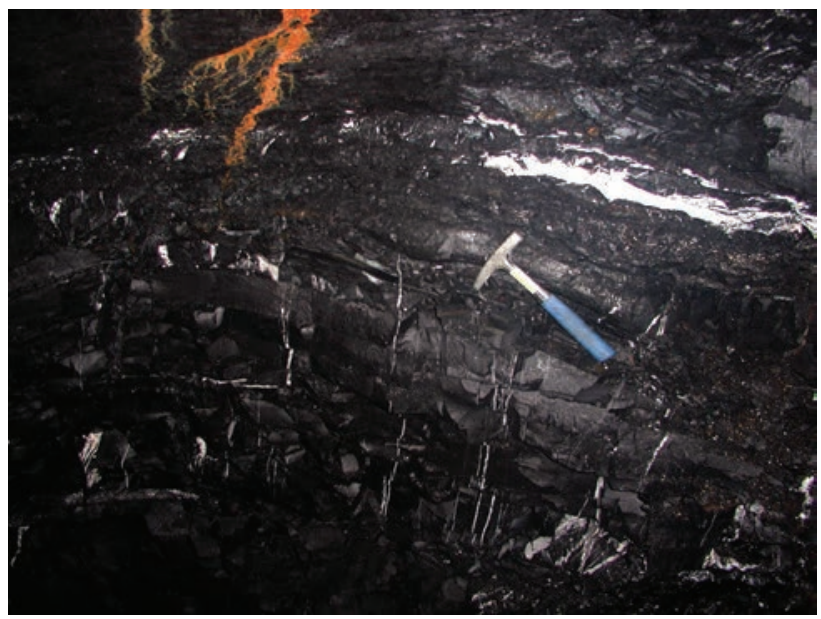

Fig. 3 Location of Ni-Mo horizon in the mine (placement of the hammer). Note near vertical white fracture quartz-carbonate fillings (photo by J. Pašava).

corrections were performed for interferences involving $\mathrm{Ru}-\mathrm{Rh}$ and $\mathrm{Rh}-\mathrm{Pd}$. The results are listed in Tab. 1 .

\section{Results}

Despite of the relatively high concentration of PGE in the studied samples ( $\mathrm{PGE} \sim 1 \mathrm{ppm})$, no specific PGM have been found. However concentrations of Rh, Pt, Pd and Re detectable with the electron microprobe, have been found in grainy pyrite, millerite and gersdorffite (Tab. 1, Fig. 6). Rhodium occurs in pyrite (up to $220 \mathrm{ppm}$ ) and in millerite

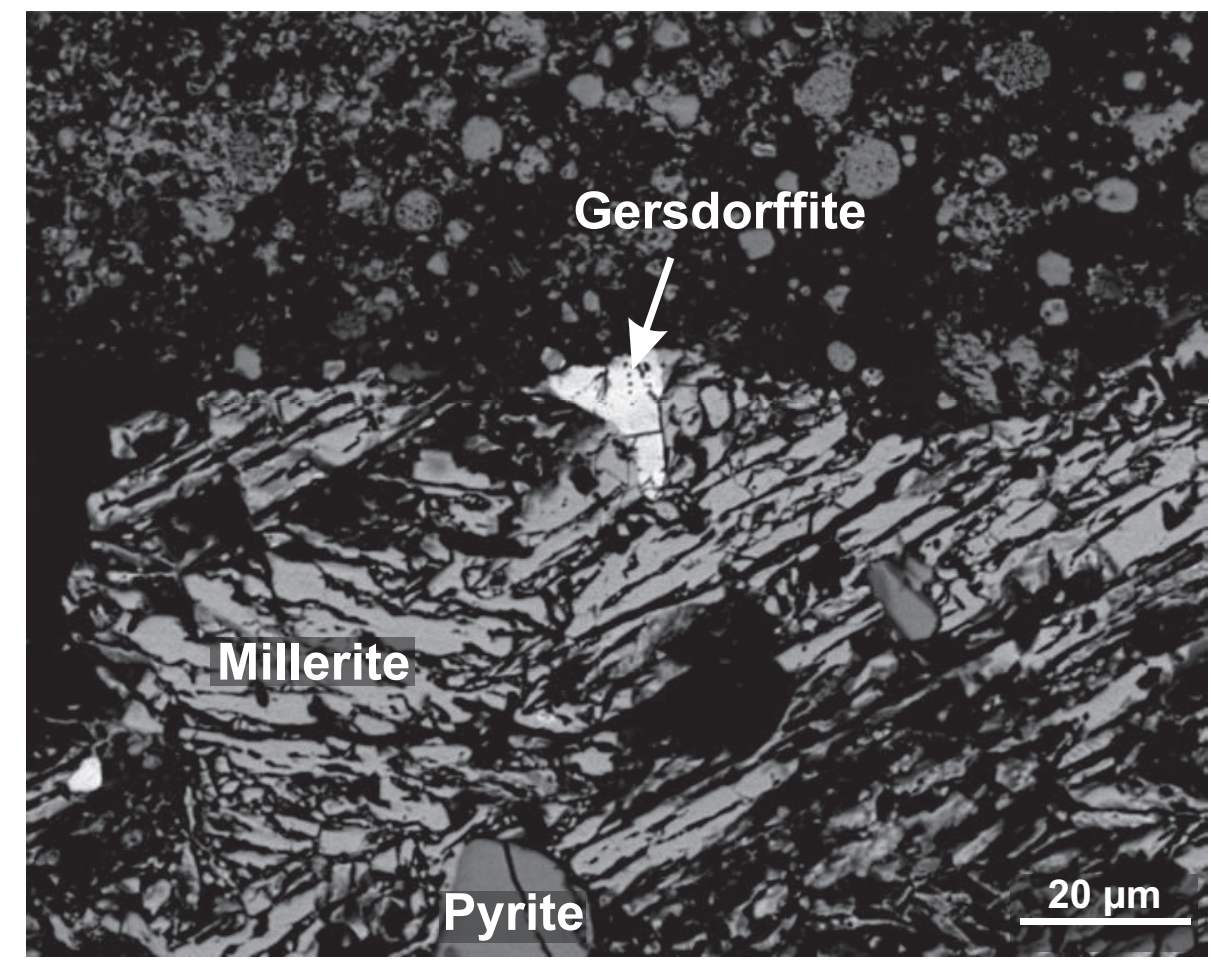


Tab. 1 PGE and Re concentrations in pyrite (grainy), millerite and gersdorffite from Mo-Ni-PGE black shale (Huangjiawan mine, Zunyi region, Guizhou Province, south China) (ppm)

\begin{tabular}{|c|c|c|c|c|c|c|c|c|c|}
\hline Pyrite & $\mathrm{n}$ & NA & Mean & Std & Min & $25 \%$ & Median & $75 \%$ & $\operatorname{Max}$ \\
\hline $\mathrm{Rh}$ & 164 & 329 & 60 & 50 & 10 & 30 & 50 & 90 & 220 \\
\hline $\mathrm{Pt}$ & 258 & 235 & 130 & 100 & 10 & 60 & 110 & 190 & 500 \\
\hline $\mathrm{Pd}$ & 292 & 201 & 120 & 80 & 10 & 60 & 100 & 160 & 390 \\
\hline $\mathrm{Re}$ & 205 & 288 & 140 & 120 & 10 & 50 & 110 & 180 & 1060 \\
\hline \multicolumn{10}{|c|}{ Millerite } \\
\hline $\mathrm{Rh}$ & 71 & 177 & 60 & 40 & 10 & 20 & 50 & 90 & 190 \\
\hline $\mathrm{Pt}$ & 137 & 111 & 150 & 110 & 10 & 60 & 120 & 230 & 520 \\
\hline $\mathrm{Pd}$ & 133 & 115 & 100 & 80 & 10 & 40 & 80 & 150 & 430 \\
\hline \multicolumn{10}{|c|}{ Gersdorffite } \\
\hline $\mathrm{Pt}$ & 33 & 33 & 150 & 110 & 10 & 60 & 130 & 200 & 410 \\
\hline $\mathrm{Pd}$ & 39 & 27 & 130 & 80 & 10 & 80 & 120 & 190 & 320 \\
\hline
\end{tabular}

Omitted are elements which were in the given mineral consistently below the respective detection limits. These were Pd $-60 \mathrm{ppm}$, Pt $-80 \mathrm{ppm}$, $\mathrm{Rh}-50 \mathrm{ppm}, \mathrm{Re}-110 \mathrm{ppm}, \mathrm{Ru}-60 \mathrm{ppm}$

NA - not available

(up to $190 \mathrm{ppm}$ ), but not in gersdorffite. Platinum was found in all the minerals with concentration up to 500, 520 and 410 ppm in pyrite, millerite and gersdorffite, respectively. The highest concentration of Pd (430 ppm) was found in millerite, whereas pyrite and gersdorffite contain 390 and 320 ppm of Pd, respectively. Rhenium was found only in pyrite, reaching up to $1060 \mathrm{ppm}$. Ruthenium was always below detection limit of $60 \mathrm{ppm}$.

\section{Discussion}

In the following text we discuss the presence of PGM in different types of mineralizations associated with black shales worldwide and compare them with the studied

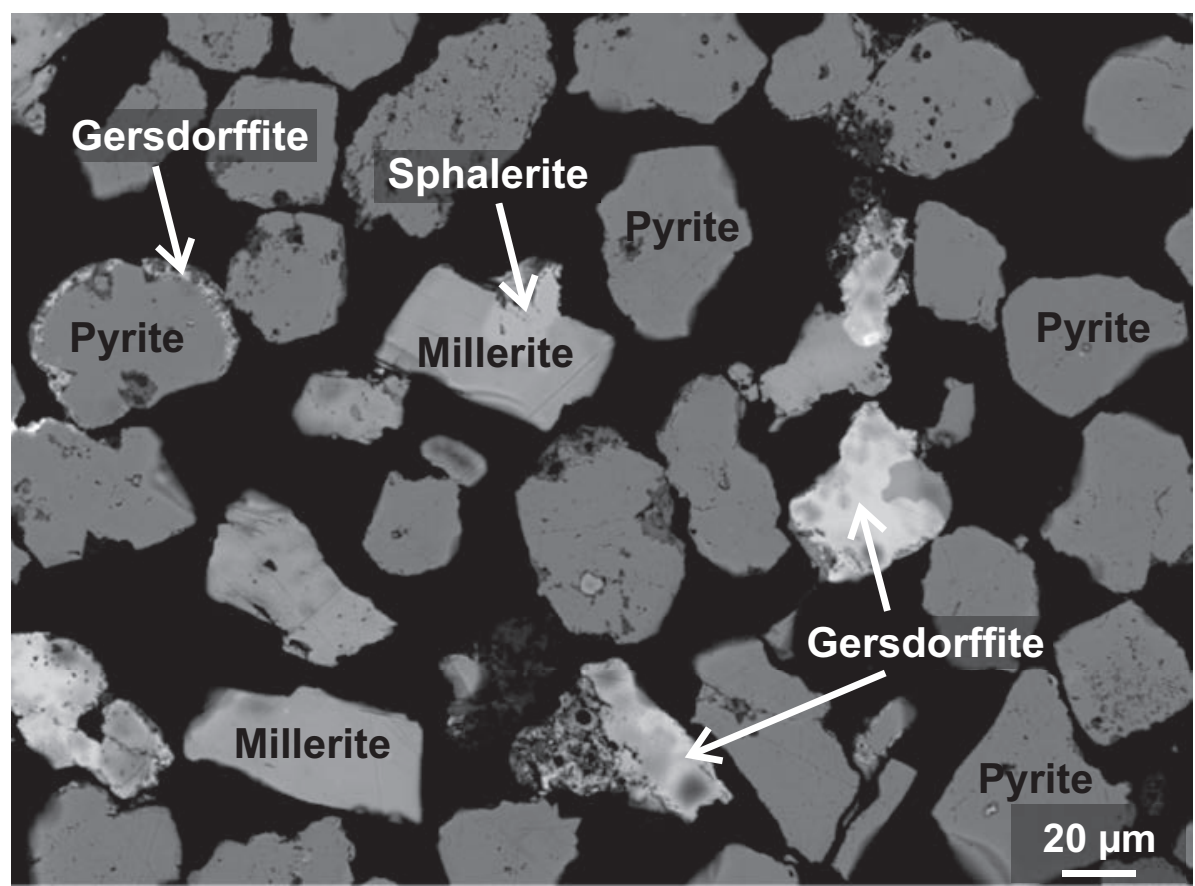

samples. Anomalous PGE concentrations of 10-370 ppm Pt and 10-120 ppm Pd (locally, up to $1000 \mathrm{ppm}$ ) were reported by Kucha (1982) from a thin noble metal-rich layer within the Polish $\mathrm{Cu}-\mathrm{Ag}$ ores of the Kupferschiefer type. Kucha (1981) noted that Pt and Ir occur in the Kupferschiefer noble metal layer as admixtures in $\mathrm{Au}-\mathrm{Pt}$ solid solutions and in other cases Pt and Ir form organometallic compounds - possibly metallocenes. Palladium is present in several minerals and phases: as native palladium, $\mathrm{PdBi}$ (sobolevskite), $\mathrm{Pd}_{3} \mathrm{As}_{5}, \mathrm{PdAs}_{2}, \mathrm{Pd}_{3} \mathrm{As}_{2},(\mathrm{Pd}, \mathrm{Au})_{5} \mathrm{As}_{2}$, $\mathrm{Pd}_{3} \mathrm{As}$ (possibly vincentite), $\mathrm{Pd}_{8} \mathrm{As}_{2} \mathrm{~S}, \mathrm{Pd}_{4} \mathrm{As}_{3}$, palladium hydroxides of arsenic, $\mathrm{PdNiAs}$ (majakite), $\mathrm{PdCu}(\mathrm{As}, \mathrm{S})_{6}$, and $\mathrm{Pd}_{8} \mathrm{As}_{6} \mathrm{~S}_{3}$, and as $\mathrm{Pd}_{2} \mathrm{As}$ palladoarsenide, Kucha 1975). Palladium is also concentrated in $\mathrm{Ni}$ and Co arsenides (up to 5.5 and 2.5 wt. \%, respectively). The $\mathrm{Pd}$ content in organic matter is far lower than that of $\mathrm{Pt}$ and $\mathrm{Ir}$ and as a rule does not exceed $0.3 \mathrm{wt}$. $\%$. In extreme cases, however, $\mathrm{Pd}$ reaches 2 wt. $\%$ and is associated with $\mathrm{Bi}, \mathrm{Pt}$, sometimes $\mathrm{Sn}$, and up to $2 \mathrm{wt}$. \% of S (Kucha 1982).

Mitrofanov et al. (1994) identified cooperite (PtS) as inclusions (in size of $0.3-0.5$ $\mu \mathrm{m})$ in pyrite of Au-ore hosted by black shales of Riphean age at the Sukhoy Log deposit (Russia). The study of ultraheavy concentrate from these Au-orebearing black shales resulted in the identification of native (?) $\mathrm{Pt}$, isoferroplatinum $\left(\mathrm{Pt}_{3} \mathrm{Fe}\right)$,

Fig. 5 Backscattered electron image of sulfide concentrate, photo by F. Zaccarini. 
tetraferroplatinum $(\mathrm{PtFe})$ and $\mathrm{Pt}-\mathrm{Fe}-\mathrm{Cu}$ inclusions in $\mathrm{Au}-$ bearing pyrite and a $(\mathrm{Pd}, \mathrm{Ag})(\mathrm{Te}, \mathrm{Bi})$ phase, which was intergrown with galena and sphalerite (Distler et al. 1998).

New type of PGE mineralization was described by Chernyshov and Korobkina (1995) from Proterozoic black shales of the Voronezh Crystalline Massif. Rudaschevsky et al. (1995) reported the presence of native $\mathrm{Pd}, \mathrm{Pt}, \mathrm{Au}-\mathrm{Pt}-\mathrm{Pd}, \mathrm{PdSn}_{2}$ and $(\mathrm{Pd}, \mathrm{Pt})_{3} \mathrm{Se}_{2}$ from the same occurrence.

A PGE mineralization was reported from U-V-rich black shales of the Onega Trough (South Karelia) by Polekhovsky et al. (1991) who identified froodite $\left(\mathrm{PdBi}_{2}\right)$, sobolevskite ( $\mathrm{PdBi}$ with $\mathrm{Pt}$ and $\mathrm{Te})$, polarite $\mathrm{Pd}(\mathrm{Bi}, \mathrm{Pb})$, insizwaite $\left(\mathrm{PtBi}_{2}\right), \mathrm{Pd}, \mathrm{Pt}$ selenides (padmaite PdBiSe and sudovikovite $\mathrm{PtSe}_{2}$ ) and PGE sulfoselenides.

Discrete PGM (stibiopalladinite- $\mathrm{Pd}_{5+\mathrm{x}} \mathrm{Sb}_{2-\mathrm{x}}$, sudburyite - PdSb, native palladium, sudovikovite (Pt,Pd)Se ${ }_{2}$, a Pt$\mathrm{Pd}-\mathrm{Fe}$ alloy, native platinum, milotaite (PdSbSe), palladseite $\left(\mathrm{Pd}_{17} \mathrm{Se}_{15}\right)$ and rare bismuthian stibiopaladinite and Bi-Pd-Se phases were described by Gilbert (1987) and Carville et al. (1990) from Palaeoproterozoic U-Au-PtPd black shale hosted Coronation Hill deposit, Australia.

Canet et al. (2003) studied Silurian sedex deposits in the Poblet area in southwestern Catalonia and found sulfidic black shales which are $\mathrm{V}$ - and $\mathrm{Cr}$-rich and contain disseminated minerals bearing precious metals (e.g., sperrylite and palladian löllingite).

Despite of anomalous PGE concentrations detected in our sample of Ni-Mo-sulfidic black shales from south China, no PGM were identified in HS concentrate. Maximum Pt and Pd concentrations $(520 \mathrm{ppm}$ and $430 \mathrm{ppm}$, respectivelly) were detected in millerite which also has Rh (Tab. 1). Maximum concentrations of $\mathrm{Rh}(220 \mathrm{ppm})$ and $\operatorname{Re}(1060$ ppm) were found in pyrite, which contains on average 130 and $120 \mathrm{ppm}$ of Pt and $\mathrm{Pd}$, respectively. Gersdorffite is characterized by $\mathrm{Ru}, \mathrm{Rh}$ and Re values below the detection limits of the electron microprobe and average Pt (150 ppm) and $\mathrm{Pd}(130 \mathrm{ppm})$.

Geological and experimental data show that some sul-

Fig. 6 Box plots showing distribution of $\mathrm{Rh}, \mathrm{Pt}, \mathrm{Pd}$ and Re in pyrite, millerite and gersdorffite separated from $\mathrm{Ni}-\mathrm{Mo}-\mathrm{PGE}$ black shale. fides can incorporate significant amounts of PGE (up to several tens of percent) as solid solutions. For example, anomalous Pd concentrations were reported from native gold and pyrite at the Muruntau deposit in Uzbekistan (Rachmatullaev 1984). Similarly, Ermolayev et al. (1992) described anomalous Pd, Pt and Ir values in Au-REEPGE ores hosted by the Cambro-Ordovician marine black shales and sandstones. The PGE are concentrated in the marginal parts of pyrite, arsenopyrite and löllingite but also in REE-phosphates, graphite and quartz. Close association of PGE and organic matter has been described from the Polish Kupferschiefer (Kucha 1981) and other metal-rich black shales worldwide mostly summarized in Pašava (1993). Orberger et al. (2007) reported increased $\mathrm{Pd}$ concentrations (up to $961 \mathrm{ppm}$ ) from a Mo-S-C phase and elevated $\mathrm{Pt}$ contents from pyrite (up to 98 ppm, Pd up to $66 \mathrm{ppm}$ ) and Ni-sulfides (up to $122 \mathrm{ppm}$ Pt and up to 111 ppm Pd) in Mo-Ni-PGE black shales of South China. We found significantly higher Pt and Pd values (up to $500 \mathrm{ppm} \mathrm{Pt}$ and $390 \mathrm{ppm} \mathrm{Pd}$ ) and newly also anomalous $\mathrm{Rh}$ and $\mathrm{Re}$ concentrations (up to 220 ppm and 1060 ppm, respectively) in pyrite. Similarly, PGE contents in Ni-sulfides obtained in course of the current study are significantly higher (up to $520 \mathrm{ppm} \mathrm{Pt}$, $430 \mathrm{ppm} \mathrm{Pd}$ and $190 \mathrm{ppm} \mathrm{Rh}$ ) than those reported by Orberger et al. (2007). These authors have proposed that $\mathrm{Pd}$ was preferentially incorporated with other biophilic
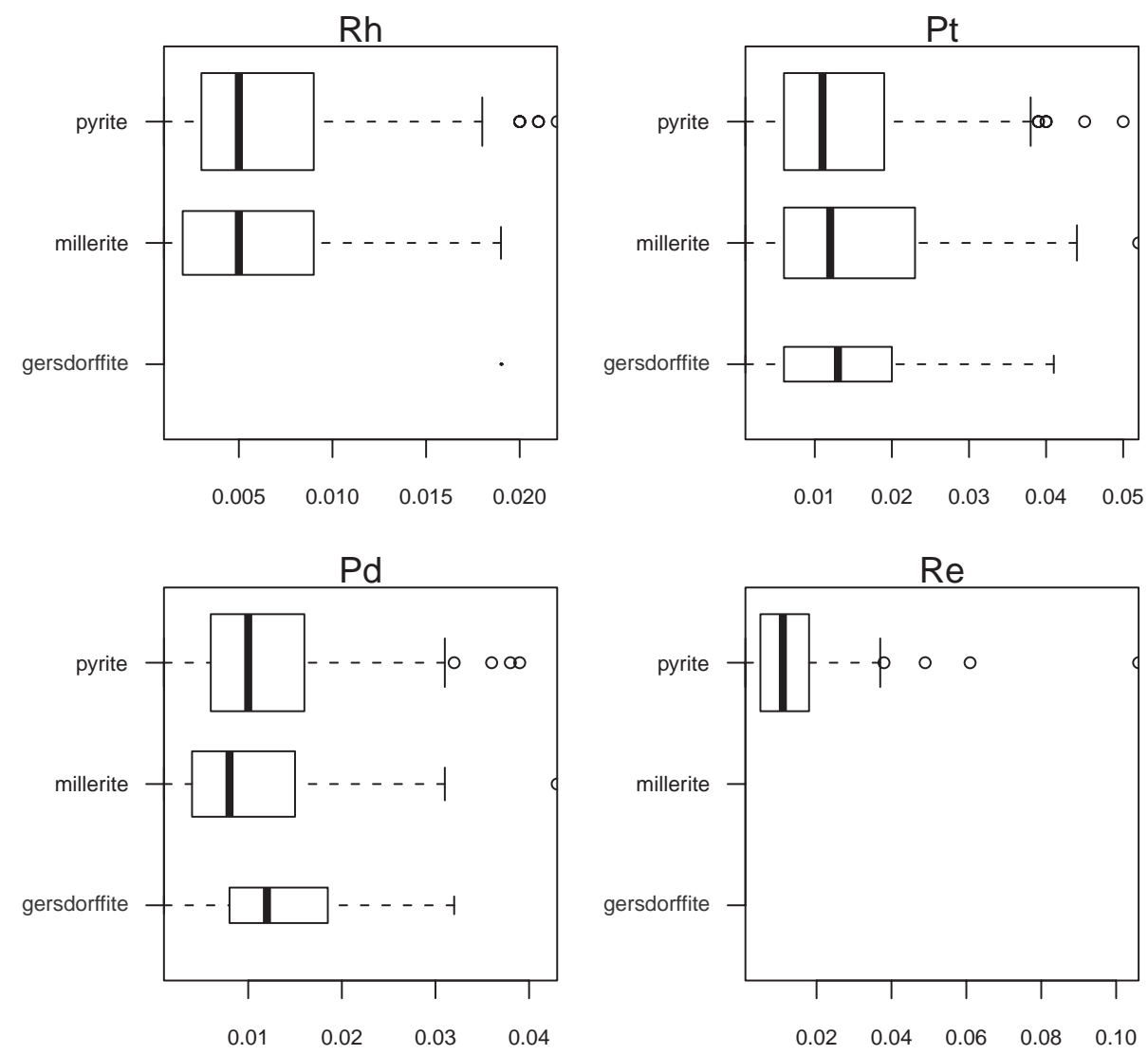
elements to Mo-S-C phase and that Pt was concentrated with less biophilic elements into pyrite and Ni-sulfides. Our data indicate that not only Pd but also Pt, Rh and Re were partitioned into pyrite and, besides Pt, also Pd and $\mathrm{Rh}$ were concentrated in Ni-sulfides. We suggest that the lack of specific PGM in our Chinese samples is related to the absence of these phases. We are aware that PGE can also occur in the form of non-traditional PGM that were reported by many authors from various occurrences. For example, oxygen-bearing compounds of $\mathrm{Pt}-\mathrm{Pd}-\mathrm{Fe}$ were described by Jedwab and Cassedanne (1998) from Minais Gerais in Brazil and Jedwab (2004) reported PGE oxides including several $\mathrm{Ru}-\mathrm{Ir}-\mathrm{Pt}-\mathrm{Ti}-\mathrm{Cr}-\mathrm{Fe}$ oxide/hydroxide compounds from Ural. It is, however, very unlikely that PGE in Mo-Ni-PGE sulfide rich black shales would be associated with such phases as they originated under anoxic environment.

\section{Conclusions}

The special separation technique applied to a $\mathrm{Mo}-\mathrm{Ni}-$ PGE black shale from the Huangjiawan mine (Guizhou Province, south China) produced a heavy separate consisting of grainy pyrite, millerite and gersdorffite. Subsequent detailed mineralogical study using electron microprobe resulted in the following findings:

1. Despite anomalous PGE concentrations ( $\mathrm{PGE} \sim 1$ $\mathrm{ppm})$ no specific platinum group minerals were identified through this study.

2. High concentrations of PGE were detected in grainy pyrite (up to $500 \mathrm{ppm} \mathrm{Pt,} 390 \mathrm{ppm}$ Pd and $220 \mathrm{ppm}$ $\mathrm{Rh}$ ), millerite (up to $520 \mathrm{ppm} \mathrm{Pt}, 430 \mathrm{ppm} \mathrm{Pd}$ and 190 ppm Rh) and gersdorffite (up to $410 \mathrm{ppm} \mathrm{Pt,} 320 \mathrm{ppm}$ $\mathrm{Pd}$ and without any $\mathrm{Rh}$ ).

3. Newly, anomalous Re concentrations (up to $1060 \mathrm{ppm}$ ) were found in grainy pyrite.

4. We suggest that besides close association of Pd with organic matter (anomalous Pd concentrations previously reported from a Mo-S-C phase) $\mathrm{Pt}, \mathrm{Rh}$ and also Re were incorporated into pyrite and also Ni-sulfides (millerite and gersdorffite).

Acknowledgements. This paper was written in honour of Prof. Zdeněk Pouba, a great personality, excellent economic geologist and University teacher of Jan Pašava. This is a contribution to the Project no. 323000 of the Strategic Research Plan (2012-2015) of the Czech Geological Survey and to the Czech-Austrian mobility program AKTION (project No. MEB061113). We thank the University Centrum for Applied Geosciences (UCAG) for the access to the E. F. Stumpfl electron microprobe laboratory. Thanks are also due to R.M. Coveney Jr. and S.Y. Jiang for stimulating reviews and D. Dolejš, with V. Janoušek for careful editorial handling.

\section{References}

Aiglsperger T, Proenza JA, Zaccarini F, Labrador M, Navarro-Ciurana D (2011) Looking for needles in a haystack: how to find PGM in laterites by using hydroseparation techniques. Macla 15: 23-24

Cabri LJ, Beattie M, Rudashevsky NS, Rudashevsky VN (2005) Process mineralogy of Au, Pd and Pt ores from the Skaergaard intrusion, Greenland, using new technology. Mineral Eng 18: 887-897

Canet C, Alfonso P, Melgarejo JC, Jorge S (2003) PGEbearing minerals in Silurian sedex deposits in the Poblet area, southwestern Catalonia, Spain. Canad Mineral 41: 581-595

Carville DP, Leckie JF, Moorhead CF, Rayner JG, Durbin AA (1990) Coronation Hill Gold-Platinum-Palladium deposit. In: Hughes FE (Ed) Geology of the Mineral Deposits of Australia and Papua New Guinea. The Australian Institute of Mining and Metallurgy, Melbourne Monographs 14, v1, pp 759-762

Chen NC, Yang X, Liu D, Xiao X, Fan DL, Wang L (1982) Lower Cambrian black argillaceous and arenaceous rock series in south China and its associated stratiform deposits. Miner Depos 1: 39-51 (in Chinese with English abstract)

Chernyshov NM, Korobkina TP (1995) New type of platinoid mineralization in the Voronez province: platinoidbearing highly carbonaceous black shales. In: ORLOV VP (ed) Platinum of Russia, vol 2, part 2. Geoinformmark Co., Moscow, pp 55-83 (in Russian)

Coveney RM JR, Chen N (1991) Ni-Mo-PGE-Au-rich ores in Chinese black shales and speculations on possible analogues in the United States. Miner Depos 26: 83-88

Coveney RM JR, Pašava J (2005) Origins of Au-Pt-Pdbearing $\mathrm{Ni}-\mathrm{Mo}-\mathrm{As}(\mathrm{Zn})$ deposits hosted by Chinese black shales. In: MAo J, BiERLin FP (eds) Mineral Deposits Research: Meeting the Global Challenge. Proceedings of the $8^{\text {th }}$ Biennial SGA Meeting, Beijing, Volume 1. Springer, Heidelberg, pp 101-102

Coveney RM JR, Murowchick JR, Grauch RI, Glascock MD, Denison JR (1991) Gold and platinum in shales with evidence against extraterrestrial sources of metals. Chem Geol 99: 101-114

Distler VV, Mitrofanov GL, Nemerov VK, Kovalenker VA, Mokhov AV, Semeikina LK, Yudovskaya MA (1998) The platinum mineralization of the Sukhoy Log gold deposit (Russia). In: LAVErov NP, Distler VV (eds) International Platinum. Theophrastus Publications, St. Petersburg-Athens, pp 178-193

Emsbo P, Zhang X, Hofstra AH, Hu R, Johnson CA, Su W, Pi D, Koenig A, Grauch R (2005) Lower Cambrian 
metallogenesis of south China: interplay between diverse basinal hydrothermal fluids and marine chemistry. In: Mao J (Ed) Mineral Deposits Research: Meeting the Global Challenge. Proceedings of the $8^{\text {th }}$ Biennial SGA Meeting, Beijing. Volume 1. Springer, Heidelberg, pp $115-118$

Ermolayev NP, Sozinov NA, Flician ES, Tsinenov VA, Khoroshilov VL (1992) New Types of Precious and Rare Earth Element Ores in Black Shales. Nauka, Moscow, pp 3-185 (in Russian)

FAN D (1983) Polyelements in the Lower Cambrian black shale series in southern China. In: Augustithis SS (Ed) The Significance of Trace Metals in Solving Petrogenetic Problems and Controversies. Theophrastus Publications S.A., Athens, pp 447-474

Gilbert DJ (1987) Mineralogical occurrence and texture of gold, platinum group minerals and other phases in heavy liquid fractions and diamond drill core samples, from Coronation Hill, Northern Territory. Melbourne BHP Melboure Research Laboratories, Petrology Section report MRL204, v. 1, pp 1-64

Grauch RI, Murowchick JB, Coveney RM Jr, Chen N (1991) Extreme concentration of Mo, Ni, PGE and $\mathrm{Au}$ in anoxic marine basins, China and Canada. In: PAgeL M, Leroy JL (Eds) Source, Transport and Deposition of Metals. Balkema, Rotterdam, pp 531-534

Hulbert LJ, Gregoire CD, Paktunc D (1992) Sedimentary nickel, zinc, and platinum-group-element mineralization in Devonian black shales at the Nick property, Yukon, Canada: a new deposit type. Explor Mineral Geol 1: $39-62$

JeDWAB J (2004) 'Irite' (Hermann, 1836/1841) from the Urals. Mineral Mag 68: 369-394

JedwaB J, CASSEDAnNe J (1998) Historical observations on oxygen-bearing compounds of platinum and palladium in Minas Gerais, Brazil. Canad Mineral 36:887-893

Jiang SY, Chen YQ, Ling HF, Yang JH, Feng HZ, Ni P (2006) Trace- and rare-earth element geochemistry and $\mathrm{Pb}-\mathrm{Pb}$ dating of black shales and intercalated $\mathrm{Ni}-\mathrm{Mo}-$ PGE-Au sulfide ores in Lower Cambrian strata, Yangtze Platform, South China. Miner Depos 41: 453-467

Jiang SY, Yang JH, Ling HF, Chen YQ, Feng HZ, Zhao $\mathrm{KD}$, NI P (2007) Extreme enrichment of polymetallic NiMo-PGE-Au in Lower Cambrian black shales of South China: an Os isotope and PGE geochemical investigation. Palaeogeogr Palaeoclimatol Palaeoecol 254: 217-228

Jiang SY, Pi DH, Heubeck C, Frimmel H, Liu YP, Deng HL, LING HF, YANG JH (2009) Early Cambrian ocean anoxia in South China. Nature 459: E5-E6

Kao LS, Peacor DR, Coveney RM Jr, Zhao G, Dungey Ke, Curtis MD, Penner-Hahn JE (2001) A C/MoS mixedlayer phase (MoSC) occurring in metalliferous black shales from southern China, and new data on jordisite. Amer Miner 86: 852-861
KŘ́íbek B, Sýkorová I, Pašava J, Machovič V (2007) Organic geochemistry and petrography of barren and Mo-Ni-PGE mineralized marine black shales of the Lower Cambrian Niutitang Formation (south China). Int J Coal Geol 72: 240-256

Kucha H (1975) Preliminary report on the occurrence of palladium minerals in the Zechstein rocks of the ForeSudetic monocline. Mineral Pol 6: 87-92

Kucha H (1981) Precious metal alloys and organic matter in the Zechstein copper deposits, Poland. Tschermaks Mineral Petrogr Mitt 28:1-16

KuchA H (1982) Platinum-group metals in the Zechstein copper deposits, Poland. Econ Geol 77: 1587-1591

Lehmann B, Nägler TF, Holland HD, Wille M, Mao J, PAN J, Dulski P (2007) Highly metalliferous carbonaceous shale and Early Cambrian seawater. Geology 35: 403-406

Lott DA, Coveney RM JR, Murowchick JB, Grauch RI (1999) Sedimentary exhalative nickel-molybdenum ores in south China. Econ Geol 94: 1051-1066

Mao J, Lehmann B, Du A, Zhang G, Ma D, Wand Y, Zeng M, KerRich R (2002) Re-Os dating of polymetallic $\mathrm{Ni}-\mathrm{Mo}-\mathrm{PGE}-\mathrm{Au}$ mineralization in Lower Cambrian black shales and its geologic significance. Econ Geol 47: 151-1061

Mao J, Cheng Y, Chen M, Pirajno F (2013) Major types and time-space distribution of Mesozoic ore deposits in South China and their geodynamic settings. Miner Depos 48: 267-294

Mitrofanov GL, Nemerov VK, Korobeinikov MK, SeMEIKINA LK (1994) Platinum-potential of late Precambrian carbonaceous formations of the Baikalo-Patomic Plateau region. In: OrLov VP (ed) Platinum of Russia, vol 2, part 2. Geoinformmark Co., Moscow, pp 150-154 (in Russian)

Orberger B, Pašava J, Gallien JP, Daudin L, Pinti D (2003) Biogenic and abiogenic hydrothermal sulfides: controls of rare metal distribution in black shales. J Geochem Explor 78-79: 559-563

Orberger B, Vymazalová A, Wagner C, Fialin M, Gallien J, Wirth R, Pašava J, Montagnac G (2007) Biogenic origin of intergrown Mo-sulphide- and carbonaceous matter in Lower Cambrian black shales (Zunyi Formation, Southern China). Chem Geol 238: 213-231

PAŠAVA J (1993) Anoxic sediments - an important source for PGE; an overview. Ore Geol Rev 8: 425-445

Pašava J., KŘ́íbek B, Žák K, Vymazalová A, Hailing D, Taiy L, Chaoyang L, Mingguo Z (2004) New data on the origin of Lower Cambrian Mo-Ni-PGE black shales in Guizhou Province, south China. Abstracts of the $32^{\text {nd }}$ International Geological Congress; 20-28 August 2004, Florence, part 2, pp 878 (A-198-15) - CD-ROM

Pašava J, KŘíbek B, Vymazalová A, SÝKorová I, Žák K, Orberger B (2008) Multiple sources of metals of 
mineralization in Lower Cambrian black shales of south China: evidence from geochemical and petrographic study. Resour Geol 58: 25-42

Pi DH, Liu CQ, Shields-Zhou GA, Jiang SY (2013) Trace and rare earth element geochemistry of black shale and kerogen in the early Cambrian Niutitang Formation in Guizhou province, South China: constraints for redox environments and origin of metal enrichments. Precambr Res 225: 218-229

Piestrzynski A, Wodzicki A, Banaszak A (1996) Gold in the copper deposits of the Fore-Sudetic Monocline (SW Poland). Przegl Geol 44: 1098-1102 (in Polish)

Pieczonka J, Piestrzynski A (1997) New minerals from the red bed type precious metal deposit of the LubinSieroszowice mining district, SW Poland. In: MAO J, BIERLIN FP (Eds) Mineral Deposits Research: Meeting the Global Challenge. Proceedings of the $8^{\text {th }}$ Biennial SGA Meeting, Beijing, Volume 2. Springer, Heidelberg, pp 1041-1044

Polekhovsky YV, Voloshin AV, Tarasova IP, Pakhomovsky YA, KRETSER YL (1991) A new type of palladium bearing mineralization in metasomatic rocks of Karelia. Izv Akad Nauk SSSR, ser Geol 7: 86-95 (in Russian)

Rachmatullaev ChR (1984) Some pecularities of the distribution of Pt and Pd in rocks of the Cental Kyzylkum area. Mining J (Uzbekistan) 8: 60-63 (in Russian)

Rudashevsky NS, Rudashevsky VN (2006) Patent of Russian Federation No 2281808, invention "Hydraulic Classifier", Moscow, August 20, 2006
Rudashevsky NS, Rudashevsky VN (2007) Patent of Russian Federation No 69418, industrial (useful) model, "Device for separation of solid particles", Moscow, December 27, 2007

Rudashevsky NS, Knauf VV, Chernyshov NM (1995) Platinum group minerals from black shales of the Kursk magnetic anomaly. Dokl Akad Nauk 344: 91-95 (in Russian)

RUdASHEVSKy NS, RUdASHEVSKY VN, LuPAL SD (2001a) Patent of Russian Federation No 2165300, invention "Hydraulic Classifier", Moscow, April 20, 2001

RUDASHEVSKY NS, RUDASHEVSKY VN, LuPAL SD (2001b) The method of separating granular materials and device for carrying out said method. Patent Cooperation Treaty (PCT), (16 March 2001) on the basis of Russian patent No 2165300, Moscow, April 20, 2001

SAwlowicz Z (1993) Iridium and other platinum-group elements as geochemical markers in sedimentary environments. Palaeogeogr Palaeoclimatol Palaeoecol 104: $253-270$

Steiner M, Wallis E, Erdtmann BD, Zhao YL, Yang RD (2001) Submarine-hydrothermal exhalative ore layers in black shales from South China and associated fossils: insights into a Lower Cambrian facies and bio-evolution. Palaeogeogr Palaeoclimatol Palaeoecol 169: 165-191

Xu LG, Lehmann B, Mao JW, Qu WJ, Du AD (2011) Re-Os age of polymetallic Ni-Mo-PGE-Au mineralization in Early Cambrian black shales of South China - a reassessment. Econ Geol 106: 511-522 